\title{
Understory Vegetative Diversity of Post-Thinned Pine Plantations Treated with Fertilizer, Fire and Herbicide in East Texas
}

\author{
Brian P. Oswald, ${ }^{1}$ Betsy Ott, ${ }^{2}$ Hans M. Williams, ${ }^{1}$ Kenneth W. Farrish, ${ }^{1}$ \\ and James E. Van Kley ${ }^{3}$ \\ ${ }^{1}$ Arthur Temple College of Forestry and Agriculture, Stephen F. Austin State University, Nacogdoches, TX 75962-6109, USA \\ ${ }^{2}$ Life Sciences Department, Tyler Junior College, TX 75701, USA \\ ${ }^{3}$ Department of Biology, Stephen F. Austin State University, Nacogdoches, TX 75962-6109, USA
}

Correspondence should be addressed to Brian P. Oswald, boswald@sfasu.edu

Received 1 July 2009; Revised 12 October 2009; Accepted 9 November 2009

Recommended by Brian C. McCarthy

\begin{abstract}
This study assessed biodiversity in the understory of two pine plantations where different management tools (fertilizer, prescribed burning, and herbicide application) were utilized. During three growing seasons, species, percent cover, and number of individuals, and physical characteristics were recorded. Responses to treatment were examined based on comparison of species richness, evenness, diversity, and importance. Two years after treatment, fertilized plots showed a decline in species richness, evenness, and diversity. Prescribed burning and herbicide treatments increased species richness but decreased species evenness, resulting in no change in diversity index. Herbicide treatment reduced the importance of dominant shrubs and increased the importance of disturbance-adapted species.
\end{abstract}

Copyright (C) 2009 Brian P. Oswald et al. This is an open access article distributed under the Creative Commons Attribution License, which permits unrestricted use, distribution, and reproduction in any medium, provided the original work is properly cited.

\section{Introduction}

Preserving biodiversity may be a management objective in both natural and planted stands [1-3], and The Society of American Foresters has recommended management of forestlands to "conserve, maintain, or enhance" biological diversity [4]. Biodiversity in managed forests was the theme of a conference in Sweden [5], and Chapin III et al. [6] demonstrated that as species diversity was reduced, the ability to tolerate environmental change declined. Several authors $[7,8]$ suggested evaluation of three types of biodiversity (structure, function, and composition) at the stand level of forest management, where forest managers have the greatest affect.

Austin [9] noted that species vary continuously in a multidimensional space, and respond differently to environmental gradients of different kinds. Reice [10] found that after disturbance, evenness is often more affected than richness, as species rarely are eliminated completely, although major shifts in dominance are common. Reice also asserted that biological communities are usually in some stage of recovery after disturbance, resulting in patchiness (heterogeneity) as different areas are at different stages of postdisturbance succession. This nonequilibrium results in higher species diversity and allows greater coexistence of similar species than would be predicted in a state of equilibrium. Species that are common in disturbed habitats may have value as wildlife forage and cover, food for migrating birds and insects, and reservoirs of genetic diversity, so patches of different successional stages can conserve biodiversity at the landscape level [11].

Pine plantations commonly come under criticism for replacing biologically diverse natural forest stands with monocultures of commercially valuable species. These plantations typically are managed without regard for the diversity of plant species that presumably were displaced at plantation establishment. While some studies [12] have shown understory biodiversity in managed plantations to be comparable to that found in naturally reforested areas, others [3] have shown reduced biodiversity. In comparison to an undisturbed forest stand, a planted stand after row thinning can have considerably more light and water reaching the 
understory, creating more heterogeneity on the forest floor [13] and other management practices could also affect understory biodiversity.

Several authors [14-17] have studied the long-term impact of overstory or understory removal on species diversity and richness, but not in southern pine plantations. Berendse [17] and Thomas et al. [16] reported decreased understory vegetation diversity after application of fertilizer, and McGee et al. [18] found an increase in understory diversity eight to twelve years after springtime prescribed burns, while Elliot et al. [19] found differential responses to prescribed burning in understory vegetation, with diversity increasing along a ridge, decreasing at mid slope, and not changing on low slope sites.

Studies have examined response of understory vegetation to treatments in power line right-of ways [14], nonindustrial private lands [15], hardwood clearcuts in the eastern U.S. [16] and western pine stands [17], while in the southeastern United States, the impact of pine straw raking on species richness and composition [20] and the impact of burning, grazing, and mechanical site preparation on species diversity [21] in pine communities have been reported.

The objective of this study was to compare the effects of management treatments on the vegetative diversity in the understory of two pine plantations. Characteristics of understory vegetative biodiversity were compared and changes within community structure were examined in plots treated with fertilizer, prescribed burns, and herbicide applications, separately and in combinations.

\section{Materials and Methods}

In 1999, two study sites with apparently similar soil, aspect, and slope within loblolly pine (Pinus taeda) pine plantations managed by International Paper Corporation (designated Cherokee Ridge and Sweet Union) were selected based on time since establishment (trees 13-17 years old) and thinned within the previous 12 months. Both sites were located in the western Gulf Coastal Plain in southern Cherokee County, Texas, on Tertiary Sandstone and Shale, in the Claiborne group (Eocene origin, 58-37 my) [22]. The area has a mean annual precipitation of $107 \mathrm{~cm}$, mean annual evaporation of $127 \mathrm{~cm}$, mean annual temperature of $18.9^{\circ} \mathrm{C}$, mean annual high temperature of $25.3^{\circ} \mathrm{C}$, and mean annual low temperature of $12.8^{\circ} \mathrm{C}$. Soils found at Cherokee Ridge were sandy loam and fine sandy loam, moderately welldrained to well-drained Darco (Grossarenic Paleudults), Tenaha (Arenic Hapludults), and a poorly drained Osier (Typic Psammaquents) on a portion of the site. Soil types identified at Sweet Union were loamy sands and included Ruston (Typic Paleudults) and Attoyac (Typic Paleudalfs) [23].

The Cherokee Ridge site was planted with genetically improved loblolly pine in 1985 and thinned in 1998 to a basal area of $5.2 \mathrm{~m}^{2} \mathrm{ha}^{-1}$, approximately 48 trees $\mathrm{ha}^{-1}$. The Sweet Union site was planted in 1982 and also thinned in 1998 to a basal area of $9.0 \mathrm{~m}^{2} \mathrm{ha}^{-1}$, or about 81 trees ha ${ }^{-1}$. Each study site was divided into five replicates and each replicate was subdivided in a split plot design, with a fertilizer application as the whole treatment and vegetation control treatments on plots. One half of each replicate was chosen randomly for fertilizer treatment; the other half remained unfertilized. Each half was divided into four 0.1 ha treatment plots, separated by buffers $\geq 10 \mathrm{~m}$, and treatments (control, herbicide, prescribed burn, or herbicide and prescribed burn) randomly assigned. A 0.04 ha measurement plot was nested within each treatment plot.

Herbicide treatment was applied in October of 1999. The herbicides were applied later than planned due to dry conditions, but the efficacy of the treatment was not impaired due to the prolonged potency of the chemicals used. Ground cover was treated with a tank mix of Accord ${ }^{\mathrm{TM}}$ (2.2 $\mathrm{L} \mathrm{ha}^{-1}$ at Cherokee Ridge; $2.5 \mathrm{~L} \mathrm{ha}^{-1}$ at Sweet Union), Chopper ${ }^{\mathrm{TM}}\left(4.5 \mathrm{~L} \mathrm{ha}^{-1}\right)$, Sun-It II oil $\left(11.2 \mathrm{~L} \mathrm{ha}^{-1}\right)$, and water $\left(17.7 \mathrm{~L} \mathrm{ha}^{-1}\right)$ : hardwood trees $\geq 4 \mathrm{~m}$ tall were treated using Arsenal $\mathrm{AL}^{\mathrm{TM}}$ by "hack and squirt". A March prescribed burn was followed by an April application of Urea and Diammonium Phosphate (DAP) at a rate of $224 \mathrm{~kg} \mathrm{ha}^{-1} \mathrm{~N}$ and $28 \mathrm{~kg} \mathrm{ha}^{-1} \mathrm{P}$.

Understory vegetation was identified to species when possible or to higher taxa (genus or family) following Hatch et al. [24]. During the time of active growth (May to July in each year of the study), at least two sets of samples were taken on each replicate. For each sample set, four $1-\mathrm{m}^{2}$ quadrats were randomly chosen within the 0.04 ha measurement plot, and a complete list of all species rooted in the quadrat recorded. For each herbaceous and shrub species, percent coverage was estimated categorically (trace; $1 \%-5 \%$; $6 \%-10 \% ; 11 \%-20 \%, 21 \%-50 \%$; $51 \%-75 \%$; $76 \%-90 \%$; and $90 \%-100 \%)$, and the number of individuals recorded and defined as stems or clumps, depending on the species. Any trees within the quadrat were also recorded. Plants were assigned to one of four layers: herbaceous (up to $1.3 \mathrm{~m}$ ), shrub (1.3-3 m), vine, and tree, and grouped into life form categories (ferns, forbs, graminoids, vines, shrubs, and trees) for comparative analyses.

Canopy cover was visually estimated to the nearest $10 \%$ directly overhead each quadrat. Areal extent of nonliving ground cover (litter, coarse woody debris) was classified in the same coverage classes as vegetation. Data from the quadrats were combined into a single set for each plot in each sample. Correlations between the vegetative data and the treatments were tested using multivariate analysis. Species richness was determined as the number of species in each treatment plot, and the Shannon Index of Heterogeneity was determined for each treatment, and evenness values were derived. Comparison of different treatments was made based on the Shannon diversity indices as well as richness and evenness. Multiple analyses of variance were used to determine differences in response to treatment for the identified community types. Response to treatment was compared for plots classified as an upland type; other community types were not represented well enough across treatments for this analysis.

Statistical comparisons were conducted using SAS version 8 [25]. Analysis of variance was determined using General Linear Model Analysis $(\alpha=0.1)$ to evaluate any 


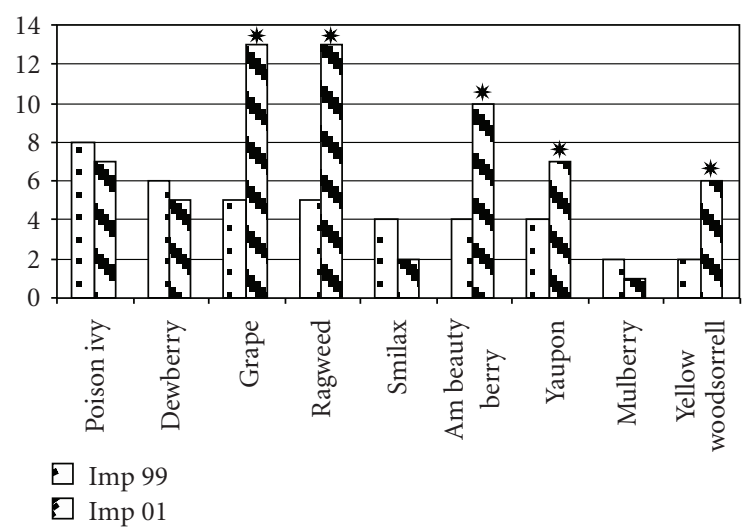

Figure 1

statistical differences due to treatments, based on species richness, species evenness and species diversity (using the Shannon index), percent of ground cover and importance. Comparisons between sites and between treatment plots were made before treatment to determine between-site and within-site homogeneity. First year posttreatment analyses did not include effects of herbicide, as most plots with herbicide applied showed little understory growth in the summer after treatment. Additionally, comparisons between years were made.

Response to treatment of specific species was also analyzed. Common species were selected for analysis due to their ubiquity in many of the plots at both sites in the first year and included American beautyberry (Callicarpa americana), late boneset (Eupatorium serotina), poison ivy (Toxicodendron radicans), and yellow wood-sorrel (Oxalis stricta). Analysis of data after the second posttreatment year included calculation of importance values of individual species, determined from relative dominance (based on percent ground cover) and relative density (based on number of individuals). Importance (I) was calculated using dominance (measured by percent ground cover) and density for each species on each plot in the monthly sample sets, then averaging the importance values for each year.

$$
\mathbf{I}=\frac{\sum_{j}(\% \text { Ground cover }+ \text { density })_{i}}{n} .
$$

The difference in I was calculated by subtracting the 1999 value from the 2001 value. A negative value indicates a decline in importance from 1999 to 2001 (Figure 1). Herbaceous and shrub species with relatively high importance values were selected for more complete comparison of treatment effects.

\section{Results}

No significant differences were found in pretreatment species richness or species diversity between the two sites, even though species-specific variability between and within sites existed. In addition, no significant differences were found in pretreatment species richness or species diversity for eight of the ten replicates. The two Cherokee Ridge replicates that
TABle 1: Percent of ground cover classes by fertilization and burning treatments within the first two posttreatment years, cherokee ridge and sweet union research sites combined, east Texas, USA. * significantly different within column at $P=.1$ from analysis of various test proc GLM (SAS, ver 8).

\begin{tabular}{lcc}
\hline Treatment & Year 1 & Year 2 \\
\hline Unfertilized, unburned & $51 \%-75 \%$ & $51 \%-75 \%$ \\
Fertilized, unburned & $51 \%-75 \%$ & $51 \%-75 \%$ \\
Fertilized, burned & $51 \%-75 \%$ & $76 \%-90 \%$ \\
Unfertilized, burned & $21 \%-50 \% *$ & $51 \%-75 \%$ \\
\hline
\end{tabular}

TABle 2: Percent of ground cover (first two posttreatment years) for all treatment combinations, cherokee ridge and sweet union research sites combined, east Texas, USA. * significantly different at $P=.1$ from analysis of various test proc GLM (SAS, ver 8 ).

\begin{tabular}{lc}
\hline Treatment & Cover class \% \\
\hline Fertilized, burned & $76 \%-90 \%$ \\
Unfertilized, unburned & $51 \%-75 \%$ \\
Fertilized, unburned & $51 \%-75 \%$ \\
Unfertilized, burned & $51 \%-75 \%$ \\
Unfertilized, burned, herbicide & $51 \%-75 \%$ \\
Fertilized, burned, herbicide & $51 \%-75 \%$ \\
Unfertilized, unburned, herbicide, & $25 \%-50 \% *$ \\
Fertilized, unburned, herbicide & $25 \%-50 \% *$ \\
\hline
\end{tabular}

bordered a streambed had steeper slopes, very little understory, and a thick layer of pine needles with significantly lower species richness ( $F$ value of $9.96 ; P<.0001)$ and species diversity ( $F$ value of $4.62 ; P=.0003$ ) than the other Cherokee replicates. No significant difference was found in species richness or species diversity among treatments. A significant reduction in percent ground cover class was identified in plots treated with prescribed burning but unfertilized ( $P$ $<.0001$ ), but this effect was gone at the end of year two (Table 1). Plots with herbicide applied were not included in analysis in the first posttreatment year, as most herbicidetreated plots had little or no vegetation. Expansion to include the herbicide treatment by year two (Table 2) showed a significantly lower percent ground cover for those plots that were unburned with herbicide, with or without fertilizer.

Measures of alpha diversity included Shannon index of diversity, species richness, and evenness (Table 3 ). The untreated control showed a higher level of diversity and evenness, although there was no significant difference in richness except for those fertilized and unburned. The fertilized treatment resulted in significantly lower species richness, but not diversity. When all treatments were collapsed to compare individual treatments (Table 4), the difference between fertilized and unfertilized plots was still apparent. Fertilization reduced species diversity and its components. Burning resulted in higher richness but lower evenness, and herbicide application resulted in higher richness with no significant difference in evenness or Shannon indices.

At Cherokee Ridge, the effect of fertilizer reduced diversity (due to lower richness), but not at Sweet Union, even 
TABLE 3: Alpha diversity measures combined for all replicates and only the upland replicates (riparian replicates eliminated at cherokee ridge site), cherokee ridge and sweet union research sites combined, east Texas, USA. * significantly different at $P=.1$ from other treatments within column from analysis of various test proc GLM (SAS, ver 8).

\begin{tabular}{|c|c|c|c|c|c|c|}
\hline \multirow[t]{2}{*}{ Treatment } & \multicolumn{2}{|c|}{ Shannon index of diversity } & \multicolumn{2}{|c|}{ Species richness } & \multicolumn{2}{|c|}{ Species evenness } \\
\hline & All & Upland & All & Upland & All & Upland \\
\hline Control & $0.92 *$ & $0.99 *$ & 16 & 18 & $0.77^{*}$ & $0.80^{*}$ \\
\hline Fertilized, unburned & 0.77 & 0.76 & $14^{*}$ & $13^{*}$ & 0.70 & 0.70 \\
\hline Unfertilized, burned & 0.89 & 0.83 & 17 & 17 & 0.72 & 0.680 \\
\hline Fertilized, burned & 0.86 & 0.84 & 17 & 18 & 0.70 & 0.68 \\
\hline Unfertilized, unburned, herbicide & 0.89 & 0.89 & 18 & 18 & 0.74 & 0.73 \\
\hline Fertilized, unburned, herbicide & 0.84 & 0.83 & 16 & 16 & 0.71 & 0.69 \\
\hline Unfertilized, burned, herbicide & 0.88 & 0.81 & 20 & 20 & 0.69 & 0.63 \\
\hline Fertilized, burned, herbicide & 0.83 & 0.85 & 19 & 19 & 0.66 & 0.68 \\
\hline
\end{tabular}

TABle 4: Main treatment effects on alpha diversity at combined cherokee ridge and sweet union research sites, east Texas, USA. * significantly higher at $P=.1$ from other treatments within column from analysis of various test proc GLM (SAS, ver 8).

\begin{tabular}{lccc}
\hline Treatment & $\begin{array}{c}\text { Shannon index } \\
\text { of diversity }\end{array}$ & $\begin{array}{c}\text { Species } \\
\text { richness }\end{array}$ & $\begin{array}{c}\text { Species } \\
\text { evenness }\end{array}$ \\
\hline Fertilized & 0.82 & 16 & 0.69 \\
Unfertilized & $0.89^{*}$ & $18^{*}$ & $0.72^{*}$ \\
\hline Burned & 0.85 & $18^{*}$ & 0.68 \\
Unburned & 0.86 & 16 & $0.73^{*}$ \\
\hline Herbicided & 0.85 & $18^{*}$ & 0.69 \\
Unherbicided & 0.86 & 15 & 0.74 \\
\hline
\end{tabular}

though richness was significantly lower due to fertilization. Burning increased richness, but not evenness or diversity, at both sites. Herbicide application resulted in higher richness but lower evenness at Sweet Union and also lower richness at Cherokee Ridge (Table 5).

Changes in importance across all treatments from 1999 to 2001 for some species were found (Table 6); species were selected based on high importance values in either 1999 or 2001 and are arranged in order of declining importance in 1999. Species that increased in importance at both sites included American beautyberry and yellow woodsorrell; these were the only two measured that increased in importance at Cherokee Ridge. Species that increased in importance at Sweet Union yet declined at the other site were ragweed (Ambrosia artemisifolia), mustang grape (Vitis mustangensis), and yaupon (Ilex vomitoria).

\section{Discussion}

Reduction in ground cover was temporary and all treatments showed the same percent of ground cover after two years other than herbicide alone, with or without fertilizer. Species richness and evenness, and therefore the Shannon index of biodiversity, declined in response to fertilization. Species richness increased after burning or herbicide application, while species evenness declined after both treatments.
At Cherokee Ridge, the untreated control had significantly higher species evenness and Shannon index only when comparing the upland plots, and at Sweet Union, the fertilized plots had a significantly lower Shannon index than all other treatments on the upland plots. The response to combined burning and herbicide application, with or without fertilizer, was a significantly greater species richness, species evenness, and biodiversity (without fertilizer).

The elimination of all but upland areas from analysis skewed the data in some aspects such as noted for late boneset (Eupatorium serotinum) and yellow wood-sorrell at Sweet Union, for which there was a large difference for upland plots compared to all plots: not surprising for late boneset, as this species was more common on upland areas. At Cherokee Ridge, late boneset increased significantly only after herbicide application and burning, whereas yellow wood-sorrel's importance was significantly higher after fertilization, alone or in combination with burning. Dewberry (Rubus spp.) also showed a difference in significance when comparing all plots to just upland plots; in this case, the Fertilizer, Herbicide treatment was significantly different for all plots, but that difference was not seen in the single upland plot, where Dewberry was not an important species to begin with. Other species more common on upland areas included goatweed (Croton capitatus), green indigo (Baptisia sphaerocarpa), ground-cherry (Physalis spp.), and ragweed. Goatweed increased in importance after fertilization, with or without burning. Green indigo, ground-cherry, and Virginia creeper (Parthenocissus quinquefolia) all increased in importance only after herbicide application without fertilization, but their patchy, limited distribution at the outset might have skewed these results. Ragweed and late boneset both showed a greater increase after a combination of herbicide application and burning, but both of these species had patchy distribution and did not consistently appear on all subplots treated with both herbicide application and prescribed burning.

Another change was the reduced importance of larger woody species (American beautyberry, yaupon) after herbicide application. The dramatic decline in dominance of large individuals after herbicide application was not offset by the increased numbers of new seedlings, an effect that would not 
TABle 5: Site-specific understory measures of alpha diversity, cherokee ridge, and sweet union research sites, east Texas, USA. * significantly different from all other treatments within column; ${ }^{+}$significantly different from the other site from analysis of various test proc GLM (SAS, ver 8).

\begin{tabular}{|c|c|c|c|c|c|c|}
\hline \multirow{2}{*}{$\begin{array}{l}\text { Treatment } \\
\text { All plots }\end{array}$} & \multicolumn{2}{|c|}{ Shannon index of diversity } & \multicolumn{2}{|c|}{ Species richness } & \multicolumn{2}{|c|}{ Species evenness } \\
\hline & $\begin{array}{l}\text { Cherokee } \\
\text { ridge }\end{array}$ & $\begin{array}{l}\text { Sweet } \\
\text { union }\end{array}$ & $\begin{array}{l}\text { Cherokee } \\
\text { ridge }\end{array}$ & $\begin{array}{l}\text { Sweet } \\
\text { union }\end{array}$ & $\begin{array}{l}\text { Cherokee } \\
\text { ridge }\end{array}$ & $\begin{array}{l}\text { Sweet } \\
\text { union }\end{array}$ \\
\hline Control & 0.91 & 0.94 & 16 & 17 & 0.76 & 0.77 \\
\hline Fertilized, unburned & 0.73 & 0.81 & 16 & $11^{*}$ & 0.61 & 0.79 \\
\hline Unfertilized, burned & 0.82 & 0.96 & 17 & 18 & 0.67 & 0.77 \\
\hline Fertilized, burned & 0.79 & 0.92 & 17 & 17 & 0.66 & 0.74 \\
\hline Unfertilized, burned, herbicide & 0.87 & 0.91 & 16 & 19 & 0.74 & 0.73 \\
\hline Fertilized, unburned, herbicide & 0.81 & 0.86 & $14^{+}$ & 17 & 0.72 & 0.69 \\
\hline Unfertilized, burned, herbicide & 0.88 & 0.88 & $18^{+}$ & $21^{*}$ & 0.70 & 0.67 \\
\hline Fertilized, burned, herbicide & 0.76 & 0.91 & 15 & $23^{*}$ & 0.65 & 0.67 \\
\hline \multicolumn{7}{|l|}{ Upland plots } \\
\hline Control & $1.01^{*}$ & 0.98 & 18 & 18 & $0.80^{*}$ & 0.80 \\
\hline Fertilized, unburned & 0.77 & $0.75^{*}$ & 16 & $11^{*}$ & 0.65 & 0.76 \\
\hline Unfertilized, burned & 0.73 & 0.93 & 16 & 18 & 0.61 & 0.75 \\
\hline Fertilized, burned & 0.76 & 0.92 & 19 & 17 & 0.61 & 0.74 \\
\hline Unfertilized, burned, herbicide & 0.86 & 0.91 & 16 & 19 & 0.73 & 0.73 \\
\hline Fertilized, unburned, herbicide & 0.78 & 0.87 & $14^{+}$ & 18 & 0.69 & 0.69 \\
\hline Unfertilized, burned, herbicide & 0.85 & $0.78^{*}$ & $18^{+}$ & $22 *$ & 0.68 & $0.58^{*}$ \\
\hline Fertilized, burned, herbicide & 0.81 & 0.89 & 16 & $22 *$ & 0.69 & $0.66^{*}$ \\
\hline
\end{tabular}

TABle 6: Change in importance values (IV) of herbaceous and shrub species at cherokee ridge and sweet union research sites, east Texas, USA between 1999 (pretreatment) and 2001 (2 years posttreatment. *significantly different at $P=.1$ from analysis of various test proc GLM (SAS, ver 8 ).

\begin{tabular}{lcccc}
\hline & Sweet union & \multicolumn{3}{c}{ Cherokee ridge } \\
\hline Species & 1999 & 2001 & 1999 & 2001 \\
\hline American beautyberry & 4 & $10^{*}$ & 6 & $24^{*}$ \\
Poison Ivy & 8 & 7 & 6 & 0 \\
Grape & 5 & $13^{*}$ & 2 & 1 \\
Ragweed & 5 & $13^{*}$ & 3 & 0 \\
Smilax & 4 & 2 & 5 & 1 \\
Yellow wood-sorrell & 2 & $6^{*}$ & 3 & $8^{*}$ \\
Yaupon & 4 & $7^{*}$ & 2 & 1 \\
Mulberry & 2 & 1 & - & - \\
Blackberry & - & - & 2 & 0 \\
Virginia creeper & - & - & 2 & 1 \\
Bitterweed & - & - & 2 & 0 \\
\hline
\end{tabular}

occur in species whose size at maturity is not that different from one- or two-year-old plants.

\section{Conclusions}

The impact of fertilizer in reducing biodiversity is well known across different ecosystems, including aquatic systems. The increases in IV seen in this study were most pronounced in American beautyberry and yellow wood-sorrell at Cherokee Ridge and in ragweed, American beautyberry, yaupon, and yellow wood-sorrell at Sweet Union. All of these species have significant wildlife value, so although the application of fertilizer could arguably be criticized as a management practice that enhances productivity of the crop tree at the expense of maintaining understory diversity, the increase in dominance of species with value to wildlife might offset the criticism.

Although there was no consistent trend in this study that indicated an increase in alpha diversity after vegetative control treatments, there was considerable evidence that diversity can increase in some circumstances. Species richness increased at both sites after burning and at Sweet Union after herbicide application, indicating that disturbance was followed by colonization by a greater number of species than were found before treatment. This data could support forest managers in decisions that must incorporate the value of maximizing diversity along with optimizing productivity in timber management.

\section{References}

[1] A.B. Carey and R.O. Curtis, "Conservation of biodiversity: a useful paradigm for forest ecosystem management," Wildlife Society Bulletin, vol. 24, no. 4, pp. 610-620, 1996.

[2] J. F. Franklin, "Structural and functional diversity in temperate forests," in Biodiversity, J. F. Franklin, Ed., pp. 166-175, NAS, Washington, DC, USA, 1988.

[3] A. J. Hansen, T. A. Spies, and F. J. Swanson, "Conserving biodiversity in managed forests: lessons from natural forests," BioScience, vol. 41, pp. 382-392, 1991.

[4] Society of American Foresters, "Biological diversity in forest ecosystems," Journal of Forestry, vol. 90, pp. 42-43, 1991. 
[5] L. Gustafsson and J. Weslien, "Preface," Forest Ecology and Management, vol. 115, no. 2-3, pp. 97-99, 1999.

[6] F. S. Chapin III, O. E. Sala, I. C. Burke, et al., "Ecosystem consequences of changing biodiversity," BioScience, vol. 48, no. 1, pp. 45-52, 1998.

[7] R. F. Noss, "Indicators for monitoring biodiversity: a hierarchical approach," Conservation Biology, vol. 4, no. 4, pp. 355364, 1990

[8] M. R. Roberts and F. S. Gilliam, "Patterns and mechanisms of plant diversity in forested ecosystems: implications for forest management," Ecological Applications, vol. 5, no. 4, pp. 969977, 1995.

[9] M. P. Austin, "The potential contribution of vegetation ecology to biodiversity research," Ecography, vol. 22, no. 5, pp. 465-484, 1999.

[10] S. R. Reice, "Nonequilibrium determinants of biological community structure," American Scientist, vol. 82, no. 5, pp. 424-435, 1994.

[11] B. H. Walker, "Biodiversity and ecological redundancy," Conservation Biology, vol. 6, no. 1, pp. 18-23, 1992.

[12] T. E. Yorks and S. Dabydeen, "Seasonal and successional understory vascular plant diversity in second-growth hardwood clearcuts of western Maryland, USA," Forest Ecology and Management, vol. 119, no. 1-3, pp. 217-230, 1999.

[13] F. S. Gilliam, N. L. Turrill, and M. B. Adams, "Herbaceous layer and overstory species in clearcut and mature central Appalachian hardwood forest," Ecological Applications, vol. 5, no. 4, pp. 947-955, 1995.

[14] J. O. Luken, A. C. Hinton, and D. G. Baker, "Response of woody plant communities in power-line corridors to frequent anthropogenic disturbance," Ecological Applications, vol. 2, no. 4, pp. 356-362, 1992.

[15] T. S. Fredericksen, B. D. Ross, W. Hoffman, et al., "Shortterm understory plant community responses to timberharvesting intensity on non-industrial private forestlands in Pennsylvania," Forest Ecology and Management, vol. 116, no. 1-3, pp. 129-139, 1999.

[16] S. C. Thomas, C. B. Halpern, D. A. Falk, D. A. Liguori, and K. A. Austin, "Plant diversity in managed forests: understory responses to thinning and fertilization," Ecological Applications, vol. 9, no. 3, pp. 864-879, 1999.

[17] F. Berendse, "Implications of increased litter production for plant biodiversity," Trends in Ecology and Evolution, vol. 14, no. 1, pp. 4-5, 1999.

[18] G. G. McGee, D. J. Leopold, and R. D. Nyland, "Understory response to springtime prescribed fire in two New York transition oak forests," Forest Ecology and Management, vol. 76, no. 1-3, pp. 149-168, 1995.

[19] K. J. Elliott, R. L. Hendrick, A. E. Major, J. M. Vose, and W. T. Swank, "Vegetation dynamics after a prescribed fire in the southern Appalachians," Forest Ecology and Management, vol. 114, no. 2-3, pp. 199-213, 1999.

[20] L. A. Kelly, T. R. Wentworth, and C. Brownie, "Short-term effects of pine straw raking on plant species richness and composition of longleaf pine communities," Forest Ecology and Management, vol. 127, no. 1-3, pp. 233-247, 2000.

[21] C. E. Lewis, B. F. Swindel, and G. W. Tanner, "Species diversity and diversity profiles: concept, measurement, and application to timber and range management," The Journal of Range Management, vol. 41, pp. 466-469, 1988.

[22] D. Spearing, Roadside Geology of Texas, Mountain Press, Missoula, Mont, USA, 1991.

[23] S. A. Wilson, K. W. Farrish, B. P. Oswald, H. M. Williams, and J. L. Yeiser, "Effects of mid-rotation intensive silviculture on forest soils in east Texas: first year results," in Proceedings of the 11th Biennial Southern Silvicultural Research Conference, K. Outcalt, Ed., Gen. Tech. Rep. SRS-48, pp. 35-37, U.S. Department of Agriculture, Forest Service, Southern Research Station, Asheville, NC, USA, 2002.

[24] S. L. Hatch, K. N. Gandhi, and L. E. Brown, Checklist of the Vascular Plants of Texas, MP-1665 Texas Agricultural Experiment Station and Texas A\&M University System, College Station, Tex, USA, 1990.

[25] SAS Institute Inc., SAS/STAT, Users Guide, Version 8, SAS Institute, Cary, NC, USA, 1999. 

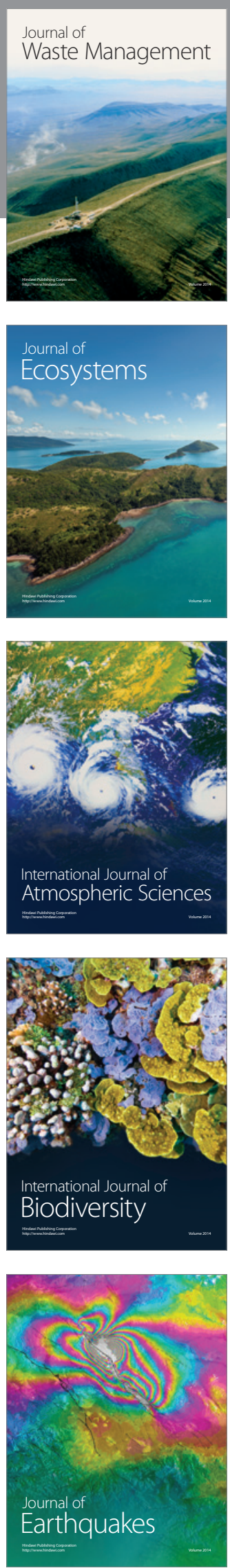
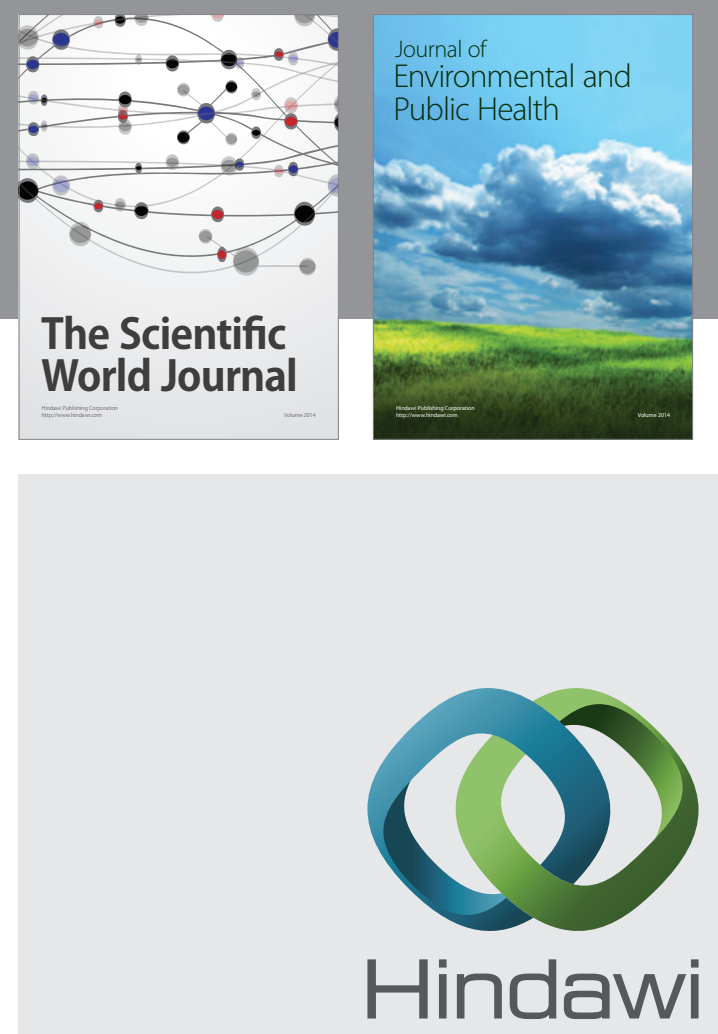

Submit your manuscripts at

http://www.hindawi.com
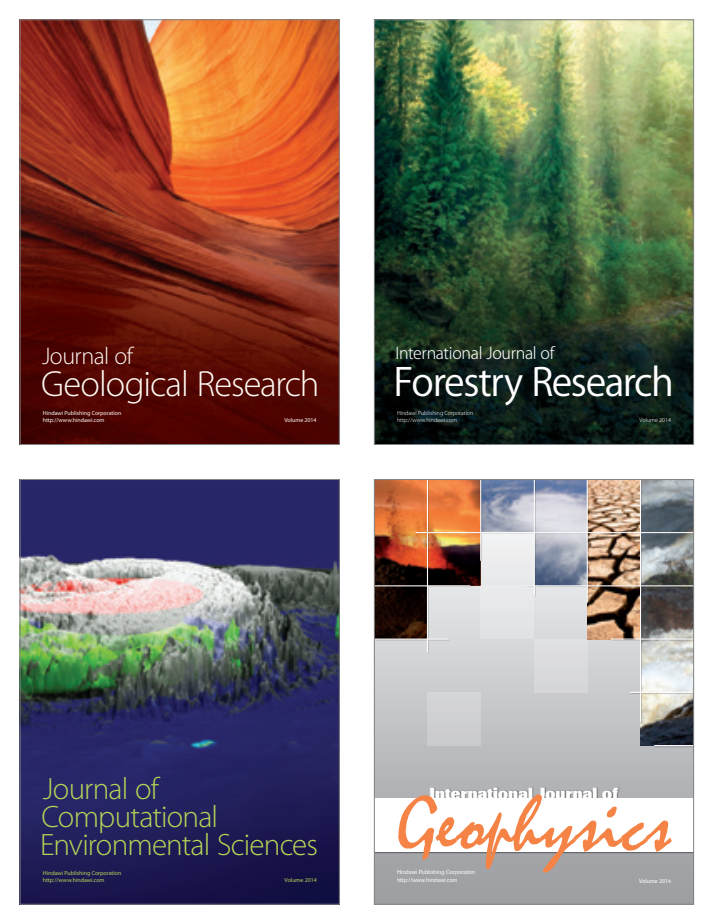
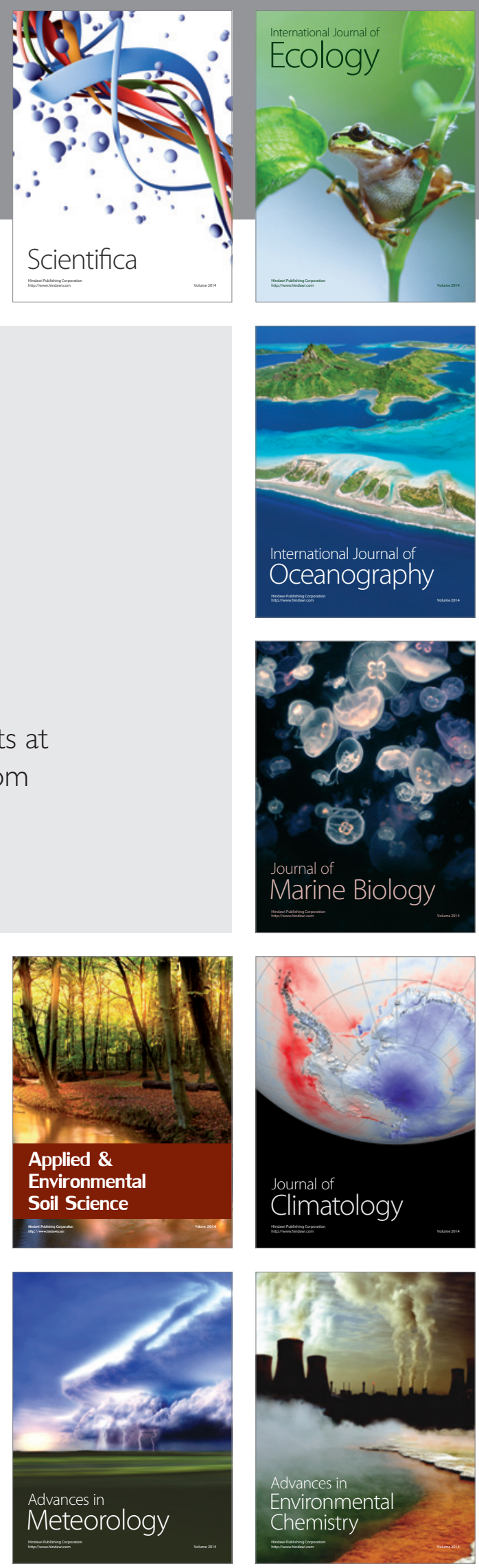